\title{
METODE MENENTUKAN KEBUTUHAN ARMADA PENJUALAN: STUDI KASUS CABANG JAKARTA DARI LIGI PERUSAHAAN ASURANSI UMUM DI INDONESIA
}

\author{
Brata Wibawa Djojo \\ Jurusan Manajemen, Fakultas Ekonomi dan Bisnis, Bina Nusantara University \\ Jl. K.H. Syahdan No. 9, Kemanggisan, Palmerah, Jakarta Barat 11480 \\ brata@binus.ac.id
}

\begin{abstract}
Many companies face a classic problem in sales people's turn-over or under-target because of uncompeteny of sales people or highly unreasonable sales target. On the other side, management has a perception that the sales people they have are uncompetence and more recruitment for sales people is not reasonable with cost and budget. If the company can not determine the sales force size, it will make a bad culture and business would not run properly. Through this research, the simply formulation will be applied at Jakarta Branch of a general insurance company LIGI (JLIGI) to their sales force at the existing condition and including in 2011. The formulations that will be applied for JLIGI are using breakdown method, workload method, and incremental method. Those three methods have each advantage and disadvantage, whereas breakdown method is a simple and general method, workload method is a more structural method and incremental method needs cost and profitability analysis of the years.
\end{abstract}

Keywords: sales person, sales target, time allocation, productivity per sales person

\begin{abstract}
ABSTRAK
Kendala yang dihadapi oleh kebanyakan perusahaan untuk armada penjualannya adalah tingkat turnover karyawan yang tinggi atau tidak tercapainya target penjualan karena armada penjualan yang tidak kompeten atau target yang ditentukan terlalu tinggi. Di lain pihak, adanya anggapan dari pihak manajemen bahwa armada penjualan tidak kompeten dan permintaan terhadap penambahan sumber daya manusia dirasakan sebagai pemborosan biaya. Melalui penelitian ini, penulis hendak melakukan perumusan sederhana terhadap program penjualan di cabang Jakarta perusahaan asuransi umum LIGI (JLIGI) terhadap armada penjualan yang dimiliki termasuk perencanaan di tahun 2011. Salah satu perumusan yang dilakukan adalah menentukan banyaknya armada penjualan yang perlu diperhitungkan oleh JLIGI dari tahun ke tahun, dengan metode penguraian (breakdown method), metode beban pekerjaan (workload method) dan metode penambahan (incremental method). Pada penerapan ketiga metode tersebut masing-masing mempunyai kelebihan dan kekurangan, di mana metode penguraian merupakan metode yang paling sederhana, metode beban pekerjaan merupakan metode yang lebih terstruktur dan metode penambahan memerlukan analisis biaya dan tingkat profitabilitas dalam tahun bersangkutan.
\end{abstract}

Kata kunci: tenaga penjual, target penjualan, alokasi waktu, profuktifitas per tenaga penjual 


\section{PENDAHULUAN}

Keberhasilan suatu perusahaan dalam mencapai target penjualan dalam satu tahun sangat dipengaruhi oleh aktivitas dan kinerja yang dilakukan oleh tim penjualan dari perusahaan tersebut. Bilamana aktivitas dan kinerja yang dilakukan oleh setiap tenaga penjual dalam perusahaaan tersebut sudah mencapai titik maksimal sedangkan target penjualan masih belum tercapai, maka kemungkinan besar yang terjadi adalah kurangnya tenaga penjual yang dimiliki oleh perusahaan atau tidak kompetennya tenaga penjual yang ada saat ini. Namun sayangnya, kebanyakan perusahaan baru mengetahui hal ini dengan pasti di akhir tahun tutup buku, sedangkan pada lembaran awal tahun buku kebutuhan terhadap jumlah manpower tenaga penjual di tahun terkait masih berupa perencanaan dan estimasi budget yang belum tentu terealisasi.

Kasus serupa yang dialami oleh cabang Jakarta dari LIGI (JLIGI), yaitu salah satu cabang dari perusahaan asuransi umum di Indonesia, di mana kebutuhan terhadap sumber daya manusia khususnya di bidang penjualan seringkali masih menjadi kendala. Di satu sisi, penetapan target penjualan dari tahun ke tahun yang selalu meningkat (tidak mungkin turun) sehingga manajer cabang selalu mengajukan penambahan jumlah orang dalam armada penjualan di setiap tahun; di sisi lain, manajemen perusahaan menganggap bahwa kapasitas tim penjualan saat ini masih mampu menangani portofolio yang dibebankan dan juga adanya anggapan bahwa penambahan jumlah orang dalam armada penjualan merupakan penambahan biaya tetap yang seharusnya dapat dioptimalkan dari komposisi armada penjualan saat ini, bukan penambahan tenaga penjual baru.

Mengacu pada kondisi tersebut di atas, maka penulis hendak melakukan analisis terhadap kebutuhan armada penjualan dihubungkan dengan metode ilmiah yang tersedia, yaitu: metode penguraian (breakdown method), metode beban pekerjaan (workload method) dan metode penambahan (incremental method) agar dapat memberikan usulan solusi terhadap permasalahan yang dialami oleh JLIGI.

\section{METODE PENELITIAN}

Menurut Johnston \& Marshall (2006), dalam menentukan armada penjualan tergantung pada tiga keputusan yang saling terkait, yaitu: (1) ukuran armada penjualan atau banyaknya wilayah penjualan, (2) desain masing-masing wilayah penjualan, dan (3) alokasi dari total usaha penjualan dalam pembukuan. Untuk menentukan ukuran armada penjualan dapat digunakan beberapa cara, namun yang paling popular adalah dengan menggunakan metode penguraian (breakdown), beban pekerjaan (work load), dan penambahan (increment). Lebih lanjut, Johnston \& Marshall (2006) menjelaskan bahwa metode penguraian (breakdown method) adalah metode yang sangat sederhana. Setiap tenaga penjual diasumsikan memiliki produktifitas dengan potensi yang sama. Untuk menentukan jumlah armada penjualan yang dibutuhkan yaitu dengan cara membagi antara total target penjualan dengan estimasi produktifitas setiap tenaga penjual.

$$
\mathrm{N}=\mathrm{S} / \mathrm{P}
$$

Di mana, $\mathrm{N}=$ jumlah tenaga penjual yang dibutuhkan

$\mathrm{S}=$ volume target penjualan

$\mathrm{P}=$ estimasi produktifitas setiap tenaga penjual

Metode ini hanya dapat digunakan sebagai estimasi kebutuhan armada penjualan secara umum, karena mengabaikan (1) kemampuan dari setiap tenaga penjual, (2) potensi yang dimiliki oleh setiap pasar yang dilayani tenaga penjual, (3) tingkat persaingan antar wilayah penjualan. Selain itu, metode ini tidak dapat dipakai untuk menghitung profitabilitas karena kebutuhan jumlah tenaga 
penjualan ditentukan oleh sebuah fungsi dari tingkat peramalan penjualan, bukan ditentukan oleh profit yang telah ditentukan.

Metode berikutnya yang disampaikan oleh Johnston \& Marshall (2006) adalah metode beban pekerjaan (workload method). Ketentuan dasar atau asumsi dalam menentukan jumlah armada penjualan dengan metode ini adalah seluruh tenaga penjual harus memikul tanggung jawab yang sama. Beberapa tahapan dalam metode ini adalah mengklasifikasikan seluruh pelanggan dalam suatu kategori; menentukan frekuensi dan rentang penjualan dalam setiap kategori; menghitung beban pekerjaan dalam satu cakupan pasar; menentukan waktu luang per tenaga penjual; membagi waktu tenaga penjual dengan tugas yang dilakukan; menghitung jumlah tenaga penjualan yang dibutuhkan.

Metode beban pekerjaan (workflow method) atau disebut juga sebagai metode penumpukkan (buildup method) merupakan metode yang umum digunakan untuk menentukan banyaknya armada penjualan, di mana mudah dimengerti dan usulan yang diberikan bisa lebih baik. Sayangnya, metode ini tidak memperbolehkan adanya perbedaan kemampuan atau respon yang diberikan antar tenaga penjual ketika menerima permintaan pasar. Misalnya, tenaga penjual A merespon permintaan pasar dalam waktu 1 (satu) minggu, sedangkan tenaga penjual B merespon permintaan pasar dalam waktu 2 (dua) minggu; padahal mungkin saja perbedaan tersebut dikarenakan perbedaan jenis produk atau jarak distribusi produk.

Metode ketiga yang diangkat oleh Johnston \& Marshall (2006: 158-159) adalah metode penambahan (increment method). Tenaga penjual baru dapat direkrut sepanjang penambahan profit yang dihasilkan dapat melebihi total biaya yang dikeluarkan. Metode ini lebih bersifat empiris terhadap perhitungan budget yang tersedia, di mana terjadinya penurunan tingkat pengembalian bisa saja diakibatkan oleh adanya penambahan tenaga penjual dalam armada penjualan. Dari ketiga metode yang disampaikan oleh Johnston \& Marshall, metode ini adalah metode yang tersulit untuk diterapkan karena meskipun biaya penambahan tenaga penjual dapat diestimasikan, namun untuk melakukan estimasi profit tidak mudah dihitung, tergantung dari seberapa jauh profit yang dapat dihasilkan oleh setiap tenaga penjual, struktur wilayah penjualan, dan seberapa besar tingkat keefektifitasannya.

Dari ketiga metode yang diangkat Johnston, solusi yang dapat diberikan agar terdapat kesetaraan dalam kualitas pada tenaga penjual adalah dengan melakukan pelatihan. Kecepatan respon yang setara (metode kedua) hanya dapat dilakukan bilamana tenaga penjual memiliki tingkat pembelajaran dan kemampuan yang sama. Tingkat pembelajaran tenaga penjual adalah memahami lingkungan pekerjaan dan keterlibatan dalam aktivitas sehingga meningkatkan tingkat keahlian dan pengetahuan mereka (Bell, Mengüç \& Widing, 2010). Tingkat pembelajaran dapat dilakukan melalui pelatihan yang berfokus pada keahlian tenaga penjual menangani pelanggan secara berkualitas, "Training should focus on increasing the employee's customer-qualification skills. An effective approach is to have experienced salespeople train less experienced salespeople on (a) which customer traits to observe, (b) how to recognize those traits, and (c) which selling strategies might be mist appropriate for specific customer categories” (Román \& Iacobucci, 2010).

Seorang tenaga penjual akan cepat dalam melakukan respon bilamana mendapatkan informasi mengenai pelanggan secara baik, dengan asumsi bahwa tingkat motivasi, keahlian dan kemampuan setiap tenaga penjual adalah sama. Román \& Iacobucci (2010: 363) menjelaskan bahwa, "Salespeople have the opportunity to gather information and then develop and implement a sales presentation tailored to the characteristics of each customer. Salespeople can observe their customers' reactions to a given sales pitch and make nearly instantaneous strategic adjustments." 


\section{HASIL DAN PEMBAHASAN}

\section{Metode Penguraian (Breakdown Method)}

Berdasarkan data tahun 2008, 2009 dan 2010 berturut-turut, JLIGI mempunyai target penjualan olimpik sebesar Rp. 34 Miliar, Rp. 37 Miliar, dan Rp. 42,5 Miliar. Target olimpik adalah target yang ditetapkan di atas target normal (moderate) atau target bawah. Perhitungan dalam penelitian ini menggunakan angka pada target olimpik, bukan target normal atau target bawah. Jumlah tenaga penjual bisnis direct (karyawan) selama 3 tahun di atas berturut-turut adalah 11 orang, 11 orang, dan 12 orang. Di tahun 2011, target yang ditetapkan adalah sebesar Rp. 50 Miliar dengan jumlah tenaga penjual bisnis direct (karyawan) di awal tahun sebanyak 10 orang.

Mengacu pada data tahun 2008 sebagai patokan data awal, maka perhitungan rata-rata penjualan per tenaga penjual adalah sebesar Rp. 3,09 Miliar (Rp. 34 Miliar dibagi dengan 11 orang tenaga penjual). Dengan menetapkan asumsi bahwa estimasi produktifitas setiap tenaga penjual adalah sebesar Rp.3,09 Miliar, maka perhitungan terhadap kebutuhan armada penjualan JLIGI setiap tahun dengan menggunakan metode pertama Johnston adalah sebanyak: (1) 11 orang pada tahun 2008, (2) 12 orang pada tahun 2009, (3) 14 orang pada tahun 2010, (4) 17 orang pada tahun 2011 (Tabel 1).

Tabel 1 Kebutuhan Armada Penjualan dengan Menggunakan Metode 1 Johnston

\begin{tabular}{|c|c|c|c|c|}
\hline & 2008 & 2009 & 2010 & 2011 \\
\hline Target Penjualan & Rp. 34,000 Miliar & Rp. 37,000 Miliar & Rp. 42,500 Miliar & Rp. 50,000 Miliar \\
\hline $\begin{array}{l}\text { Estimasi Produktifitas } \\
\text { per Tenaga Penjual }\end{array}$ & Rp. 3,090 Miliar & Rp. 3,090 Miliar & Rp. 3,090 Miliar & Rp. 3,090 Miliar \\
\hline $\begin{array}{l}\text { Jumlah Tenaga Penjual } \\
\text { yang Dibutuhkan } \\
\text { Jumlah Tenaga Penjual di }\end{array}$ & 11 orang & $\begin{array}{r}11,97 \text { orang } \rightarrow \\
12 \text { orang }\end{array}$ & $\begin{array}{r}13,75 \text { orang } \rightarrow \\
14 \text { orang }\end{array}$ & $\begin{array}{r}16,18 \text { orang } \rightarrow \\
17 \text { orang }\end{array}$ \\
\hline $\begin{array}{l}\text { Awal Tahun Berjalan } \\
\text { (Kekurangan)/Kelebihan }\end{array}$ & 11 orang & 11 orang & 12 orang & 10 orang \\
\hline Tenaga Penjual & - & (1 orang) & (2 orang) & (7 orang) \\
\hline
\end{tabular}

\section{Metode Beban Pekerjaan (Workload Method)}

Perhitungan kebutuhan armada penjualan dengan metode kedua adalah dengan menggunakan metode beban pekerjaan. Analisis untuk setiap tahapan metode ini adalah sebagai berikut.

\section{Mengklasifikasikan Seluruh Pelanggan dalam Suatu Kategori}

Seluruh pelanggan JLIGI dapat dikategorikan dalam setiap jenis produk yang dimiliki: (1) produk asuransi kebakaran dan property, (2) produk asuransi kendaraan bermotor, (3) produk asuransi pengangkutan barang, (4) produk asuransi lainnya. Di setiap kategori produk asuransi terbadi menjadi 4 golongan pelanggan, yaitu: platinum, gold, silver, dan bronze. Kriteria dari golongan pelanggan platinum adalah para pelanggan yang kontribusi preminya telah mencapai Rp. 100 juta ke atas dalam 1 tahun. Kriteria kedua yaitu gold adalah para pelanggan yang kontribusinya premi dari Rp. 10 juta hingga Rp. 99,99 juta per tahun, demikian juga untuk kriteria ketiga dan keempat berturut-turut adalah para pelanggan yang kontribusi preminya di atas Rp. 1 juta hingga Rp. 9,99 juta per tahun dan di bawah Rp. 1 juta per tahun. Seluruh golongan pelanggan dalam setiap kategori produk dapat dilihat pada Tabel 2. 
Tabel 2 Golongan Pelanggan JLIGI dalam Setiap Produk (account)

\begin{tabular}{lrcccc}
\hline & $\begin{array}{c}\text { Kebakaran } \\
\text { \& Properti }\end{array}$ & $\begin{array}{c}\text { Kendaraan } \\
\text { Bermotor }\end{array}$ & $\begin{array}{c}\text { Pengangkutan } \\
\text { Barang }\end{array}$ & Lain-Lain & $\begin{array}{c}\text { Total per } \\
\text { Golongan }\end{array}$ \\
\hline Platinum & 6 & 17 & 7 & 4 & 34 \\
Gold & 55 & 101 & 10 & 21 & 187 \\
Silver & 302 & 128 & 33 & 34 & 497 \\
Bronze & 37 & 51 & 35 & 55 & 178 \\
\hline \multicolumn{1}{c}{ Total } & 400 & 297 & 85 & 114 & 896 \\
\hline
\end{tabular}

Sumber: Data JLIGI 2010 yang diolah

\section{Menentukan Frekuensi dan Waktu yang Dialokasikan untuk Menangani Suatu Account}

Berbeda dengan metode Johnston yang menghitung langkah kedua ini dengan lamanya menghubungi setiap pelanggan melalui telepon, perhitungan untuk kasus JLIGI adalah dengan menghitung waktu yang dialokasikan untuk bertemu pelanggan dalam setiap kategori. Perbedaan ini karena sifat produk yang tidak bias dijelaskan per telepon dan adanya perbedaan kasus, namun secara keseluruhan dan inti dari perhitungan ini adalah sama.

Berdasarkan dari pengalaman JLIGI, untuk melakukan pendekatan, presentasi, negosiasi, dan me-maintain pelanggan per golongan, waktu yang dialokasikan relatif sama, namun dikarenakan adanya tingkat kompleksitas dan lebih komprehensifnya produk untuk golongan platinum, maka biasanya waktu yang dialokasikan untuk mempresentasikan dan me-maintain golongan tersebut lebih banyak. Sebagai contoh, untuk mem-followup suatu account asuransi kebakaran dan properti terhadap pelanggan industri (yang biasanya masuk dalam golongan platinum atau gold) dibutuhkan alokasi total waktu rata-rata selama 8 jam per account, dibandingkan dengan mem-followup suatu account untuk pelanggan ritel (produk asuransi kebakaran rumah tinggal) yang umumnya masuk dalam golongan silver atau bronze (total waktu rata-rata selama 2 jam per account). Detil pengalokasian waktu per kategori produk mengacu pada data JLIGI pada tahun 2010 dan dapat dilihat pada Tabel 3a, 3b, 3c, dan 3d.

Tabel 3 Frekuensi dan Waktu yang Dialokasikan untuk Menangani suatu Account Produk Asuransi Kebakaran dan Properti

\begin{tabular}{lcccc}
\hline & $\begin{array}{r}\text { Jumlah } \\
\text { Pelanggan }\end{array}$ & $\begin{array}{r}\text { Alokasi Waktu } \\
\text { Rata-rata per } \\
\text { account (jam) }\end{array}$ & $\begin{array}{r}\text { Rata-rata Banyaknya } \\
\text { Kunjungan dalam 1 } \\
\text { tahun (kali) }\end{array}$ & $\begin{array}{r}\text { Banyaknya Waktu yang } \\
\text { Dialokasikan dalam 1 } \\
\text { tahun (jam) }\end{array}$ \\
\hline Platinum & 6 & 10 & 12 & 720 \\
Gold & 55 & 10 & 8 & 4.400 \\
Silver & 302 & 4 & 2 & 2.416 \\
Bronze & 37 & 4 & 2 & 296 \\
\hline Total & 400 & & & 7.832 \\
\hline
\end{tabular}

Sumber: Data JLIGI 2010 yang diolah

Alokasi waktu yang diperlukan untuk menangani suatu account produk asuransi kebakaran dan properti untuk golongan platinum, gold, silver, dan bronze berturut-turut adalah sebanyak 10 jam, 10 jam, 4 jam, dan 4 jam. Penetapan angka ini berdasarkan pengamatan dan pengalaman di lapangan, di mana untuk meng-handle suatu account platinum diperlukan waktu untuk survey lokasi, untuk membuat proposal asuransi dan mencari dukungan reasuransi, untuk melakukan pertemuan dan presentasi ke pelanggan, untuk memproses polis dan mengantar polis. Untuk kunjungan berikutnya tidak memerlukan waktu untuk presentasi dan mencari dukungan reasuransi, namun dengan mengalokasikan waktu untuk kunjungan berarti juga mengantisipasi lamanya waktu perjalanan ke dan dari tempat pelanggan, di mana situasi jalan di Jakarta saat ini tidak dapat diprediksi. Khusus untuk 
account bronze, biasanya okupasi yang dijamin untuk produk asuransi kebakaran adalah rumah tinggal dan tidak diperlukan waktu yang lama untuk menari dukungan reasuransi dan atau presentasi yang kompleks, waktu yang dialokasikan hanyalah untuk melakukan survey risiko dan presentasi yang sederhana.

Hampir sama dengan produk asuransi kebakaran dan properti, produk asuransi kendaraan bermotor (Tabel 4) membutuhkan alokasi waktu yang setara yang umumnya berbentuk account kumpulan (untuk Platinum dan Gold). Waktu alokasi rata-rata per account untuk golongan platinum, gold, silver, dan bronze adalah sebanyak 10 jam, 10 jam, 4 jam, dan 4 jam.

Tabel 4 Frekuensi dan Waktu yang Dialokasikan untuk Menangani Suatu Account Produk Asuransi Kendaraan Bermotor

\begin{tabular}{lrrrr}
\hline & $\begin{array}{r}\text { Jumlah } \\
\text { Pelanggan }\end{array}$ & $\begin{array}{r}\text { Alokasi Waktu } \\
\text { Rata-rata per } \\
\text { account (jam) }\end{array}$ & $\begin{array}{r}\text { Rata-rata Banyaknya } \\
\text { Kunjungan dalam 1 } \\
\text { tahun (kali) }\end{array}$ & $\begin{array}{r}\text { Banyaknya Waktu } \\
\text { yang Dialokasikan } \\
\text { dalam 1 tahun (jam) }\end{array}$ \\
\hline Platinum & 17 & 10 & 5 & 850 \\
Gold & 101 & 10 & 5 & 5.050 \\
Silver & 128 & 4 & 2 & 1.024 \\
Bronze & 51 & 4 & 2 & 408 \\
\hline Total & 297 & & & 7.332 \\
\hline Sumber: Data JLIGI 2010 yang diolah
\end{tabular}

Demikian juga untuk produk asuransi pengangkutan barang, dasar pertimbangan dan alokasi waktu rata-rata produk ini lebih singkat dari produk asuransi kebakaran dan properti maupun asuransi kendaraan bermotor, karena kebutuhan pelanggan akan polis menjadi hal prioritas dan dibutuhkan kecepatan (Tabel 5).

Tabel 5 Frekuensi dan Waktu yang Dialokasikan untuk Menangani Suatu Account Produk Asuransi Pengangkutan Barang

\begin{tabular}{lrrrr}
\hline & $\begin{array}{r}\text { Jumlah } \\
\text { Pelanggan }\end{array}$ & $\begin{array}{r}\text { Alokasi Waktu } \\
\text { Rata-rata per } \\
\text { account (jam) }\end{array}$ & $\begin{array}{r}\text { Rata-rata Banyaknya } \\
\text { Kunjungan dalam 1 } \\
\text { tahun (kali) }\end{array}$ & $\begin{array}{r}\text { Banyaknya Waktu } \\
\text { yang Dialokasikan } \\
\text { dalam 1 tahun (jam) }\end{array}$ \\
\hline Platinum & 7 & 6 & 12 & 504 \\
Gold & 10 & 6 & 12 & 720 \\
Silver & 33 & 2 & 12 & 792 \\
Bronze & 35 & 2 & 12 & 840 \\
\hline Total & 85 & & & 2.856 \\
\hline Sumber: Data JLIGI 2010 yang diolah
\end{tabular}

Tabel 6 Frekuensi dan Waktu yang Dialokasikan untuk Menangani Suatu Account Produk Asuransi Lain-Lain

\begin{tabular}{lrrrr}
\hline & $\begin{array}{r}\text { Jumlah } \\
\text { Pelanggan }\end{array}$ & $\begin{array}{r}\text { Alokasi Waktu } \\
\text { Rata-rata per } \\
\text { account (jam) }\end{array}$ & $\begin{array}{r}\text { Rata-rata Banyaknya } \\
\text { Kunjungan dalam 1 tahun } \\
\text { (kali) }\end{array}$ & $\begin{array}{r}\text { Banyaknya Waktu } \\
\text { yang Dialokasikan } \\
\text { dalam 1 tahun (jam) }\end{array}$ \\
\hline Platinu & 4 & 10 & 10 & 400 \\
m & 21 & 8 & 8 & 1.344 \\
Gold & 34 & 4 & 4 & 544 \\
Silver & 55 & 2 & 2 & 220 \\
Bronze & 114 & & & 2.508 \\
\hline Total & 2010 & & & \\
\hline
\end{tabular}

Sumber: Data JLIGI 2010 yang diolah 
Untuk produk asuransi lain-lain, karena cukup bervariasinya produk yang ada di dalam kategori ini, maka alokasi waktu rata-rata untuk setiap golongan pelanggan memiliki waktu yang relative lebih banyak dibandingkan dengan produk asuransi kendaraan bermotor maupun produk asuransi pengangkutan barang (Tabel 6).

\section{Menghitung Beban Pekerjaan dalam Satu Cakupan Pasar}

Yang dimaksud dengan menghitung beban pekerjaan dalam satu cakupan pasar adalah menghitung total alokasi waktu rata-rata per account dengan banyaknya kunjungan per tahun terhadap banyaknya pelanggan per golongan pelanggan. Total alokasi waktu untuk menangani produk asuransi kebakaran dan properti dalam satu tahun adalah sebanyak 7.832 jam (Table 3) dan untuk asuransi kendaraan bermotor sebanyak 7.332 jam (Tabel 4). Produk asuransi pengangkutan barang dan asuransi lain-lain, dapat dilihat pada Tabel 5 dan 6 dengan total waktu selama 2.856 jam dan 2.508 jam dalam setahun. Sehingga total keseluruhan dari banyaknya waktu yang dialokasikan untuk menangani seluruh produk adalah sebesar 20.528 jam dalam setahun.

\section{Menentukan Waktu Luang per Tenaga Penjual}

Dengan mengambil asumsi bahwa dalam 1 hari jumlah jam kerja adalah sebanyak 8 jam kerja dan dalam seminggu ada 5 hari kerja, maka total jam kerja dalam seminggu adalah 40 jam kerja/minggu. Jika diperhitungkan dalam waktu satu tahun dan dengan mengurangi waktu yang dipakai untuk cuti dan libur nasional, maka banyaknya jam kerja selama satu tahun adalah sebanyak: 48 minggu x 40 jam kerja/minggu $=1.920$ jam kerja per tahun .

\section{Membagi Waktu Tenaga Penjual dengan Tugas yang Dilakukan}

Pada tahap ini, ditentukan berapa banyak waktu efektif yang dimiliki oleh seorang tenaga penjual untuk bertemu atau rapat dengan pelanggan (waktu efektif berjualan) dan menangani proses administrasi dari suatu account. Waktu yang tidak efektif (waktu yang diperlukan untuk berpergian, misal: terjebak macet) tidak akan diperhitungkan sebagai bagian dari pencapaian target penjualan.

Asumsi alokasi waktu kerja dari seorang tenaga penjual adalah: waktu efektif berjualan: 50\% = 960 jam kerja per tahun; waktu mengurus administrasi : 30\% = 576 jam kerja per tahun; waktu yang diperlukan untuk berpergian : $20 \%=576$ jam kerja per tahun; total: $100 \%=1.920$ jam kerja per tahun. Sehingga waktu yang diperlukan oleh seorang tenaga penjual untuk menangani suatu account adalah sebanyak 960 jam kerja per tahun +576 jam kerja per tahun $=1.536$ jam kerja per tahun .

\section{Menghitung Jumlah Tenaga Penjualan yang Dibutuhkan}

Tahap terakhir pada metode ini adalah membagi total waktu yang dialokasikan untuk menangani seluruh produk dalam setahun dengan total waktu efektif berjualan dari seorang tenaga penjual. Total tenaga penjual yang seharusnya dibutuhkan oleh JLIGI pada tahun 2010 adalah sebanyak: 20.528 jam/1.536 jam kerja per tahun $=13,36=14$ orang.

\section{Metode Penambahan (Increment Method)}

Untuk menggunakan metode penambahan, perlu dilakukan analisis terhadap historial data terlebih dahulu, di mana historikal penjualan dari tahun 2008 hingga tahun 2010 dan produktifitas per tenaga penjual dapat dilihat pada Tabel 7. 
Tabel 7 Produktifitas per Tenaga Penjual 2008-2010

\begin{tabular}{|c|c|c|c|}
\hline & 2008 & 2009 & 2010 \\
\hline Target Penjualan & Rp. 34,000 Miliar & Rp. 37,000 Miliar & Rp. 42,500 Miliar \\
\hline Hasil Penjualan & Rp. 33,362 Miliar & Rp. 31,966 Miliar & Rp. 40.150 Miliar \\
\hline $\begin{array}{l}\text { Produktifitas per tenaga } \\
\text { Penjual }\end{array}$ & 3,033 & 2,906 & 3,346 \\
\hline $\begin{array}{l}\text { Produktifitas per tenaga } \\
\text { Penjual yang Diharapkan } \\
\text { Persentase kelebihan/ }\end{array}$ & 3,091 & 3,364 & 3,542 \\
\hline (kekurangan) usaha & $-1.91 \%$ & $-15.75 \%$ & $-5.85 \%$ \\
\hline
\end{tabular}

Sumber: Data JLIGI yang diolah

Mengacu pada data tahun 2008, total Headcount atau produktifitas per tenaga penjual yang seharusnya (yang diharapkan) adalah sebesar Rp. 3,091 Miliar per tahun, sedangkan dari hasil realisasi tercapai Rp. 3,033 Miliar per tahun yang artinya ada selisih sebesar 1,91\% dari tim penjualan JLIGI. Terjadinya selisih tersebut dapat dikarenakan usaha yang kurang maksimal yang dilakukan oleh tim penjualan JLIGI atau karena faktor lain, seperti kehilangan account yang seharusnya diperpanjang (repeat order) pada tahun bersangkutan atau dapat juga dikarenakan kurangnya tenaga penjual dalam tim tersebut. Data lain yang dapat mendukung simpulan atas terjadinya selisih di atas adalah dengan melihat komposisi data budget dan profit dari tahun 2008 hingga tahun 2010 yang dapat dilihat pada Tabel 5 di bawah ini.

Tabel 8 Beban Tim Penjualan dan Laba/Rugi 2008-2010

\begin{tabular}{lrrr}
\hline & $\mathbf{2 0 0 8}$ & $\mathbf{2 0 0 9}$ & $\mathbf{2 0 1 0}$ \\
\hline Beban Tim Penjualan & 0.58 & 0.78 & 0.83 \\
Laba/Rugi & 0.339 & 5.037 & 4.111 \\
\hline
\end{tabular}

Sumber: Data JLIGI yang diolah

Berdasarkan data pada Tabel 8, tingkat margin profitabilitas mengalami peningkatan signifikan antara tahun 2008 dan 2009, namun menurun pada tahun 2010, walaupun terjadi peningkatan pada pos beban tim penjualan. Hal ini menunjukkan bahwa terjadi efisiensi pada tahun 2009 atau tingkat risiko yang rendah sehingga memperkecil budget klaim yang dikeluarkan atau dapat juga adanya cadangan teknis yang telah dikembalikan (di-release) dari tahun 2008 ke tahun 2009. Sehingga bilamana penambahan tenaga penjual yang dilakukan pada tahun 2009, tenaga penjual yang baru dapat dimaksimalkan untuk pencapaian target penjualan. Dengan berpedoman pada data tahun 2008, di mana tingkat produktifitas seorang tenaga penjual yang seharusnya adalah sebesar Rp. 3,091 Miliar per tahun, namun secara realisasi tingkat produktifitas di bawah yang seharusnya, maka untuk mengejar target penjualan di tahun 2008, penambahan 1 orang tenaga penjual cukup realistis untuk pencapaian target di tahun 2008, tidak ada penambahan di tahun 2009 (dengan jumlah 12 orang tenaga penjual cukup untuk mencapai target 2009), dan penambahan 2 orang di tahun 2010. Selanjutnya, untuk mencapai target Rp. 50 Miliar di tahun 2011, dibutuhkan tenaga penjual sebanyak 17 orang.

\section{PENUTUP}

Metode pertama terhadap penelitian yang dilakukan lebih bersifat umum dan global, tanpa memandang seberapa besar beban pekerjaan, tingkat kemampuan, dan tingkat pengalaman dari tenaga penjual yang ada dalam armada penjualan. Penerapan beban pekerjaan pada metode kedua lebih obyektif, walaupun beban pekerjaan tersebut dihitung secara rata-rata dan alokasi waktu efektif dari setiap tenaga penjual disamaratakan antar satu penjual dengan penjual lain. Berdasarkan data historikal 
metode ketiga, JLIGI kekurangan tenaga penjual pada tahun 2009. Dengan adanya penambahan tenaga penjual pada tahun 2010, terjadi penurunan terhadap margin profitabilitas JLIGI, namun hasil penjualan bergerak naik secara nyata dan signifikan sebesar 25,6\%. Pergerakan margin profitabilitas dan hasil penjualan dapat juga disebabkan oleh beberapa faktor lain, seperti: adanya release terhadap cadangan teknis (premi dan klaim), penambahan account atau bisnis baru. Perhitungan kebutuhan armada penjualan dengan menggunakan ketiga metode di atas masih menggunakan asumsi bahwa tingkat pengetahuan dan kemampuan dari masing-masing personil di tim penjualan adalah sama, tidak ada pembedaan walaupun personil tersebut berstatus sebagai karyawan kontrak, karyawan tetap ataupn karyawan percobaan. Kelemahan dari metode Johnston dapat diimbangi dengan adanya program pelatihan yang berkesinambungan dan berkelanjutan. Hal ini serupa seperti yang diungkapkan oleh Bell dan Roman, di mana untuk meningkatkan kesetaraan kemampuan sumber daya manusia adalah dengan mengadakan pelatihan dan kesadaran terhadap respon yang diberikan kepada permintaan pasar.

\section{DAFTAR PUSTAKA}

Bell, S. J., Mengüc, B., \& Widing, R. E. (2010). Salesperson learning, organizational learning, and retail store performance. Journal of the Academy of Marketing Science. 38 (2): 187-201.

Johnston, M. W., \& Marshall, G. W. (2006). Sales force management. New York: McGraw-Hill.

Román, S., \& Iacobucci, D. (2010). Antecedents and consequences of adaptive selling confidence and behavior: a dyadic analysis of salespeople and their customers. Journal of the Academy of Marketing Science. 38 (3): 363-382.

\section{RIWAYAT PENULIS}

Brata Wibawa Djojo lahir di kota Jakarta pada 3 Desember 1973. Penulis menamatkan pendidikan S1 di Universitas Trisakti, Jakarta dalam bidang Ekonomi Manajemen (Bisnis Internasional) pada tahun 1997, kemudian melanjutkan pendidikan S2 di Universitas Bina Nusantara dan Curtin University di bidang Magister Manajemen Sistem Informasi dan Master of Commerce (Information System) hingga tahun 2001. Saat ini bekerja sebagai Kepala Cabang untuk area Jabodetabek dan Cikarang di salah satu perusahaan asuransi umum nasional dan aktif di industri asuransi sebagai Ajun Ahli Asuransi Indonesia bidang Kerugian. Penulis juga aktif mengajar di beberapa universitas, salah satunya Universitas Bina Nusantara. 